\title{
Geographical distribution of Trypanosoma cruzi in triatomine vectors in the State of Mato Grosso do Sul, Brazil
}

\author{
Marlon Cezar Cominetti ${ }^{[1]}$, Bárbara Guimarães Csordas ${ }^{[1]}$, \\ Rodrigo Casquero Cunha ${ }^{[2]}$ and Renato Andreotti ${ }^{[3]}$
}

[1]. Programa de Pós-graduação em Doenças Infecciosas e Parasitárias, Faculdade de Medicina, Universidade Federal de Mato Grosso do Sul, Campo Grande, MS. [2]. Programa de Pós-Graduação em Biotecnologia, Universidade Federal de Pelotas, Pelotas, RS. [3]. Laboratório de Biologia Molecular, Sanidade Animal, EMBRAPA Gado de Corte, Campo Grande, MS.

\begin{abstract}
Introduction: This work presents the initial findings of a molecular epidemiological investigation of Trypanosoma cruzi in triatomine insects in State of Mato Grosso do Sul. Methods: A total of 511 triatomines from different regions of the state were examined. Deoxyribonucleic acid (DNA) was extracted from the intestinal contents of the insects using phenol-chloroformisoamyl alcohol (25:24:1). Polymerase chain reaction (PCR) using primers 121/122 targeting DNA kinetoplast (kDNA) was then performed to identify $T$. cruzi, and positive samples were subjected to PCR using the primer pair TcSC5D-F/R followed by restriction fragment length polymorphism (RFLP) with the restriction enzymes SphI and HpaI (1 U/reaction), cloning and sequencing. Results: One hundred samples were positive for $T$. cruzi, and three discrete typing units (DTUs) were identified (TcI, TcII, and TcBat). Triatoma sordida had the highest T. cruzi occurrence (83.3\%), and DTUs were found in three samples: $58.3 \%$ of the samples were TcI, $33.3 \%$ were TcII and $8.3 \%$ were TcBat. There was a clear geographical distribution of the DTUs throughout the state, with TcI, TcII and TcBat located in the center, TcI located in the east, and TcII located in the west. Conclusions: This study showed the occurrence of overlapping DTUs in State of Mato Grosso do Sul. The distributions of the DTUs were different, with TcI, TcII and TcBat in the center of the state, TcI predominantly in the east, and TcII in the west. Further studies may reveal a more defined mosaic distribution of DTUs in MS.
\end{abstract}

Keywords: Trypanosoma cruzi DTUs. PCR. Restriction fragment length polymorphism. Microscopy examination.

\section{INTRODUCTION}

Trypanosoma cruzi, a protozoan flagellate belonging to the order Kinetoplastida and family Trypanosomatidae, is the etiologic agent of Chagas disease, which is one of the most important parasitic infections in Latin America, surpassed only by malaria. Over 10 million people are infected with this parasite. The disease is a complex zoonosis, with mammals serving as reservoirs and hosts ${ }^{1}$, and is endemic to South and Central America $^{2}$ as well as some states in the United States of America ${ }^{3}$.

Transmission is primarily vectorial and occurs through parasite penetration of the host through injured skin or mucosa. The invertebrate vectors of $T$. cruzi are the triatomine insects Hemiptera, subfamily Reduviidae. Among the 138 described

Address to: Dr. Renato Andreotti. Lab. Biologia Molecular/Sanidade Animal/ EMBRAPA Gado de Corte. Av. Rádio Maia, Vila Popular, 79106-550 Campo Grande, MS, Brasil.

Phone: 5567 3368-2173

e-mail: renato.andreotti@embrapa.br

Receveid 29 September 2014

Accepted 24 November 2014 species of triatomines, only four play a direct role in the epidemiology of the parasite: Triatoma brasiliensis (Neiva, 1911), Panstrongylus megistus (Burmeister, 1835), Triatoma pseudomaculata (Corrêa e Espínola, 1964) and Triatoma sordida (Stal, 1859). In a study of triatomines in the State of Mato Grosso do Sul (MS), T. sordida was the most frequently observed species parasitized by flagellate protozoa ${ }^{4}$. The presence of three major of triatomine species was confirmed in MS: Triatoma brasiliensis (Neiva, 1911), P. megistus (Burmeister, 1835) and T. sordida (Stal, 1859), with significant infestation rates in domestic and peridomestic areas only for T. sordida ( $9.3 \%$ and $86.6 \%$, respectively). T. brasiliensis and P. megistus exhibited less than $0.2 \%$ infestation ${ }^{4}$.

Infection by $T$. cruzi is maintained in cycles of wild transmission over a broad range of mammalian reservoir hosts ${ }^{5}$. Human infection occurs due to the natural distribution of T. cruzi in triatomines that are adapted to the domestic environment or are peridomestic. However, infection also occurs orally through the ingestion of triatomines or food contaminated with the parasite, which is the most common form of transmission among wild animals, as well as through blood transfusion, organ transplantation and congenital infection ${ }^{6}$.

The population structure of the parasite is predominantly clonal, suggesting that recombination events are rare 
in nature ${ }^{7}$, although there are complex sexual processes in T. $\mathrm{cruzi}^{8}$. Nonetheless, the parasite presents considerable genetic diversity ${ }^{9-11}$.

Although intraspecific polymorphisms occur, an analysis of the isoenzyme patterns of $T$. cruzi isolates revealed three groups that are classified as zymodemes: Z1, Z2 and Z3 ${ }^{12,13}$. Subsequent studies using markers based on ribosomal gene and mini-exon (spliced leader) sequences revealed two major lineages, T. cruzi I (TcI) and T. cruzi II (TcII), and indicated the existence of hybrid lines $(\mathrm{TcI} / \mathrm{II})^{7,9,13-16}$. DNA sequencing analysis revealed that the TcI group is a relatively homogeneous clade, whereas TcII is divided into five subgroups (a-e), with two or three distinct phylogenetic clades (IIa-c) and two hybrid strains (IId and IIe) that are derived from the clades of the IIb and IIc subtypes ${ }^{13,17-20}$. A new classification of the types and subtypes divides T. cruzi into six strains called discrete typing units (DTUs), i.e., TcI, TcII, TcIII, TcIV, $\mathrm{TcV}$, and $\mathrm{TcVI}^{21}$, wherein TcI corresponds to the group TcI, TcII to subgroup TcIIb, TcIII to TcIIc, TcIV to TcIIa, TcV to TcIId, and TcVI to TcIIe. More recently, a new DTU has been described, TcBat ${ }^{22}$.

The objective of this study was to investigate the distribution of $T$. cruzi DTUs from samples of triatomines collected from entomology cores of the State Secretariat of Health of MS using molecular methods.

\section{METHODS}

\section{Study area}

The State of Mato Grosso do Sul is located in the Midwest region of Brazil and has an area of $357,145,532 \mathrm{~km}^{2}$ with 79 municipalities, an estimated population of 2,619,657 inhabitants, and a population density ${ }^{23}$ of 6.86 inhabitants $/ \mathrm{km}^{2}$. Approximately two-thirds of the state is a part of the Cerrado, a heterogeneous, floristic savannah that covers more than 2 million $\mathrm{km}^{2}$ and extends from Central Brazil to parts of Bolivia and Paraguay ${ }^{24}$. In the western area of the state lies the Pantanal, one of the richest floodplains in the world, with an abundance and diversity of wildlife, in addition to habitats with a complex mosaic of resources ${ }^{25}$.

All insects were collected from the municipalities of Jaraguari (May to August 2009 and September 2011), Rochedo, Caarapó, Douradina, Antônio João, Dourados, Terenos, São Gabriel do Oeste, Aparecida do Taboado, Paranaíba, Rio Verde de Mato Grosso, Corumbá, Miranda and Aquidauana (August 2011 to November 2012) in the State of Mato Grosso do Sul using the method described by Cominetti et al. ${ }^{26}$. The selection of municipalities was based on the collection of material by the regional units of the Coordenadoria de Controle de Vetores do Estado de Mato Grosso do Sul (CCV-MS).

\section{Survey of triatomine fauna}

Insects were collected by teams from regional units of the Coordenadoria de Controle de Vetores do Estado de Mato Grosso do Sul (CCV-MS). When found, the insects were collected and identified using the methodology described by Cominetti et al. ${ }^{26}$
The state is currently divided into five Vector Technician cores, as established by the Coordenadoria de Controle de Vetores (CCV) of the Secretaria Estadual de Saúde (SES). These cores were responsible for the collection and identification of insects as well as for parasitological examinations, i.e., both fresh and thin-layer smear preparations.

After the tests, the collected triatomines were placed in tubes containing $70 \%$ alcohol and sent to the Animal Health unit of Embrapa Beef Cattle for molecular tests, as described by Cominetti et al. ${ }^{27}$

\section{Identification of triatomines and microscopic examination}

Triatomines were identified using the dichotomous keys proposed by Carcavallo et al. ${ }^{28}$ Flagellated protozoa were detected using the method described by Souza ${ }^{29}$.

\section{DNA extraction and PCR}

DNA was extracted from insects as described by Westenberger et $\mathrm{al}^{30}$. The integrity of the DNA samples was determined via electrophoresis on a $0.8 \%$ agarose gel that was subsequently stained with ethidium bromide $\left(0.5 \mu \mathrm{g} . \mathrm{mL}^{-1}\right)$ and examined under ultraviolet light.

The DNA was quantified using a spectrophotometer (GeneQuant ${ }^{\mathrm{TM}}$ pro; Biochrom). An A260nm/A280nm ratio above 1.8 was established as ideal, and the concentration of each sample was adjusted to $20 \mathrm{ng} \cdot \mu \mathrm{L}^{-1}$.

The following primers, described by Wincker et al. ${ }^{31}$, were used for the molecular identification of T. cruzi: 121 (5'-AAATAATGTACGGG(T/L)GAGATGCATGA-3') and 122 (5'-GGTTCGATTGGGGTTGGTGTAATATA-3'). This primer pair permitted the amplification of a 330-bp fragment of the T. cruzi kinetoplast (kDNA). The amplification scheme that was used was previously described by Schijman et al. ${ }^{32}$.

Under natural conditions, triatomines are often co-infected with $T$. cruzi and Trypanosoma rangeli. Therefore, the samples were also subjected to PCR for $T$. rangeli using the primers TRF3 (5'-CCCCATACAAAACACCCTT-3') and TrR8 (5'-TGGAATGACGGTGCGGCGAC-3'), which target the conserved subtelomeric region of this species (SubTr, GenBank accession number AF426020). The amplification protocol was previously described by Chiurillo et al. ${ }^{33}$

Trypanosoma cruzi-positive samples were submitted to a second PCR targeting the TcSC5D gene (genome CL-Brener loci: TcCLB.473111.10, TcCLB.507853.10). To this end, the primers TcSC5D-fwd (5'-GGACGTGGCGTTTGATTTAT-3') and TcSC5D-rev (5'-TCCCATCTTCTTCGTTGACT-3') were used, which amplify an 832-bp fragment. The amplification protocol that was used was previously described by Cosentino and Agüero ${ }^{34}$.

The PCRs were performed in an Eppendorf AG 22331 thermocycler, and the DNA controls (T. cruzi as a positive control and T. rangeli as a negative control, as well as controls for the DTUs - TcI-VI and TcBat) were from a laboratory of the University of São Paulo (USP) and were provided by Dra. Marta M.G. Teixeira. Ultrapure water was used instead of template as an additional negative control. 
The reactions were performed in a final volume of $25 \mu \mathrm{L}$ containing 1X PCR buffer (Tris-HCl 10mM, pH 8.3; 50mM KCl), $1.5 \mathrm{mM} \mathrm{MgCl}, 0.2 \mathrm{mM}$ dNTPs, $0.2 \mathrm{pmol}$ each primer, $1 \mathrm{U}$ of Taq DNA polymerase (Platinum ${ }^{\circledR}$, Invitrogen) and $20 \mathrm{ng}$ of genomic DNA.

After electrophoresis in an agarose gel (2\%) and staining with ethidium bromide, the amplification products were visualized under UV light.

\section{Identification of DTUs using restriction enzymes}

All restriction enzymes were purchased from Promega (Southampton, UK). A $20-\mu \mathrm{L}$ aliquot of the amplification product of the TcSC5D gene was digested in a single reaction with 1U of HpaI (R6305) and $1 \mathrm{U}$ of SphI (R6265) and heated to $37^{\circ} \mathrm{C}$ for $1 \mathrm{~h}$. The resulting restriction fragments were visualized under ultraviolet (UV) light after electrophoresis on an agarose gel $(2 \%)$ and staining with ethidium bromide.

The process for identifying the DTUs followed the protocol described by Cosentino and Agüero ${ }^{34}$ and is shown in a simplified form in Figure 1.

\section{Sequencing}

The amplified gene product was purified using a TcSC5D Purelink ${ }^{\mathrm{TM}}$ Kit (Invitrogen), followed by cloning into the pGEMTeasy plasmid (Promega) according to the recommendations of the manufacturer. Sequencing was then performed using the method described by Sanger ${ }^{35}$ and an ABI 3730 DNA Analyzer (Applied Biosystems). The sequencing reactions were performed using the universal $\mathrm{T} 7$ primer for sequencing (5'-AATACGACTCACTATAG-3') and the BigDye ${ }^{\circledR}$ Terminator v3.1 Cycle Sequencing Kit. The races were performed in 36-cm capillary tubes using POP7 polymer. The obtained sequences were analyzed, and the plasmid sequences were identified and removed using BioEdit software ${ }^{36}$. The obtained sequences were compared with the sequences in the GenBank database, and a BLAST search (http://blast.ncbi.nlm.nih.gov/ Blast.cgi) was performed to determine the sequence identity ${ }^{37}$. Phylogenetic analyses were performed using the Geneious v.4.8.5 (Biomatters) software package ${ }^{38}$.

\section{RESULTS}

DNA samples from 511 triatomines from 14 different regions of State of Mato Grosso do Sul were examined. Of these, $100(19.6 \%)$ from eight municipalities were confirmed positive using PCR with primers 121/122, which target the kinetoplast deoxyribonucleic acid (kDNA) of the parasite. Of the 100 positive samples, $12(12 \%)$ were amplified with primers TcSC5D-fwd/TcSC5D-rev, which target the TcSC5D gene. It was not possible to amplify the samples from the municipalities of Corumbá and Dourados using the TcSC5D-fwd/TcSC5D-rev primers (Table 1).

Trypanosoma cruzi-positive triatomines were uncovered in samples from six municipalities. It was possible to identify T. cruzi DTUs in 12 of the samples. Three DTUs were found in T. sordida, which was the most commonly infected species (83.3\%), followed by T. matogrossensis and P. megistus (both with $8.3 \%$ infection); $58.3 \%$ of the 12 samples were TcI, 33.3\% were TcII, and $8.3 \%$ were TcBat. There was a clear geographical distribution of DTUs in the state, with

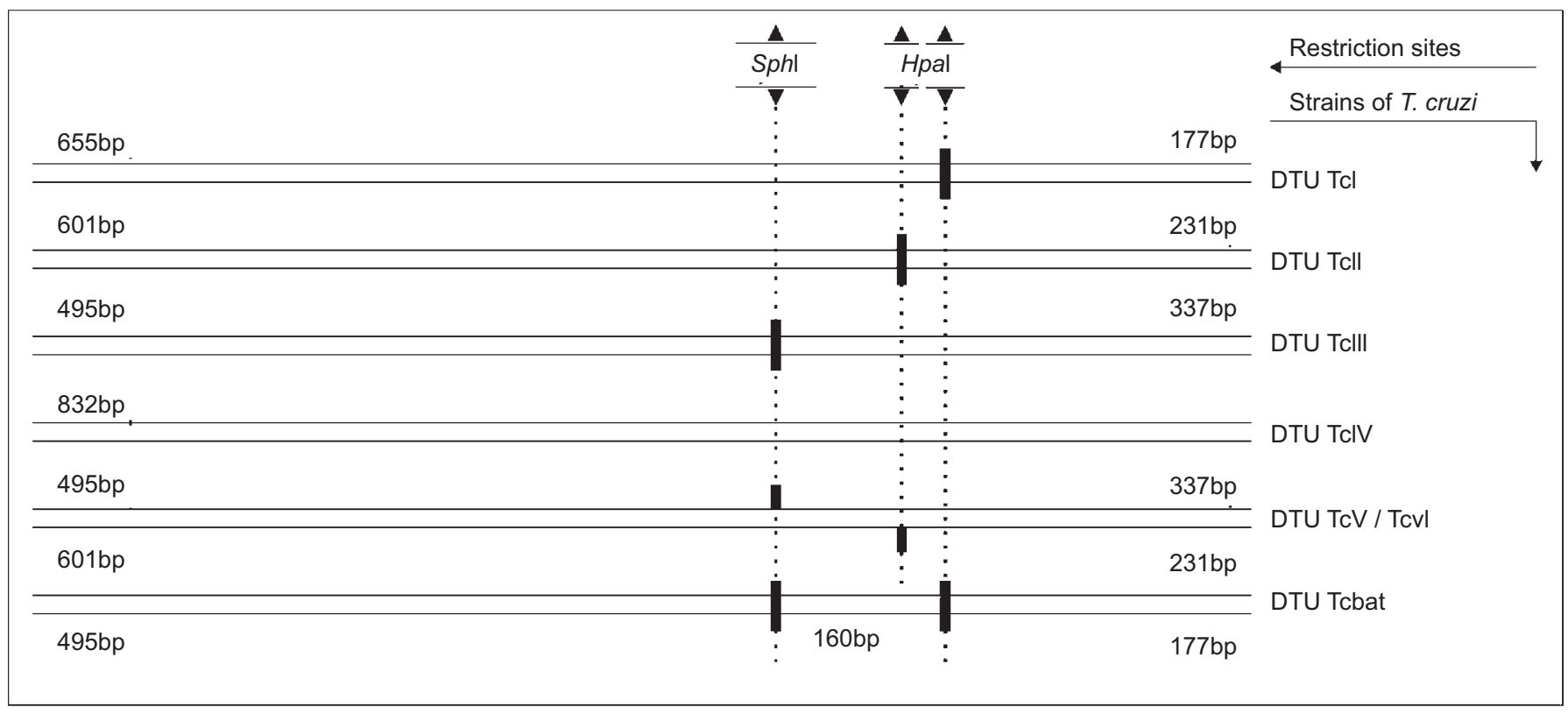

FIGURE 1 - Marker lineage using the TcSC5D gene. Simplified schematic representation of the TcSC5D amplicon and the polymorphic

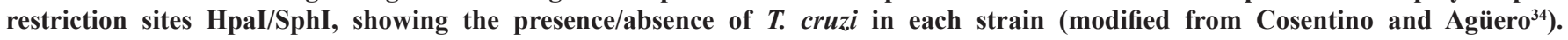
DTU: discrete typing units; T.: Trypanosoma. 
TABLE 1 - Molecular identification of Trypanosoma cruzi using primers 121/122 and the DTUs identified using primers TcSC5D-fwd/ TcSC5D-rev in triatomines found in municipalities of the State of Mato Grosso do Sul, Brazil.

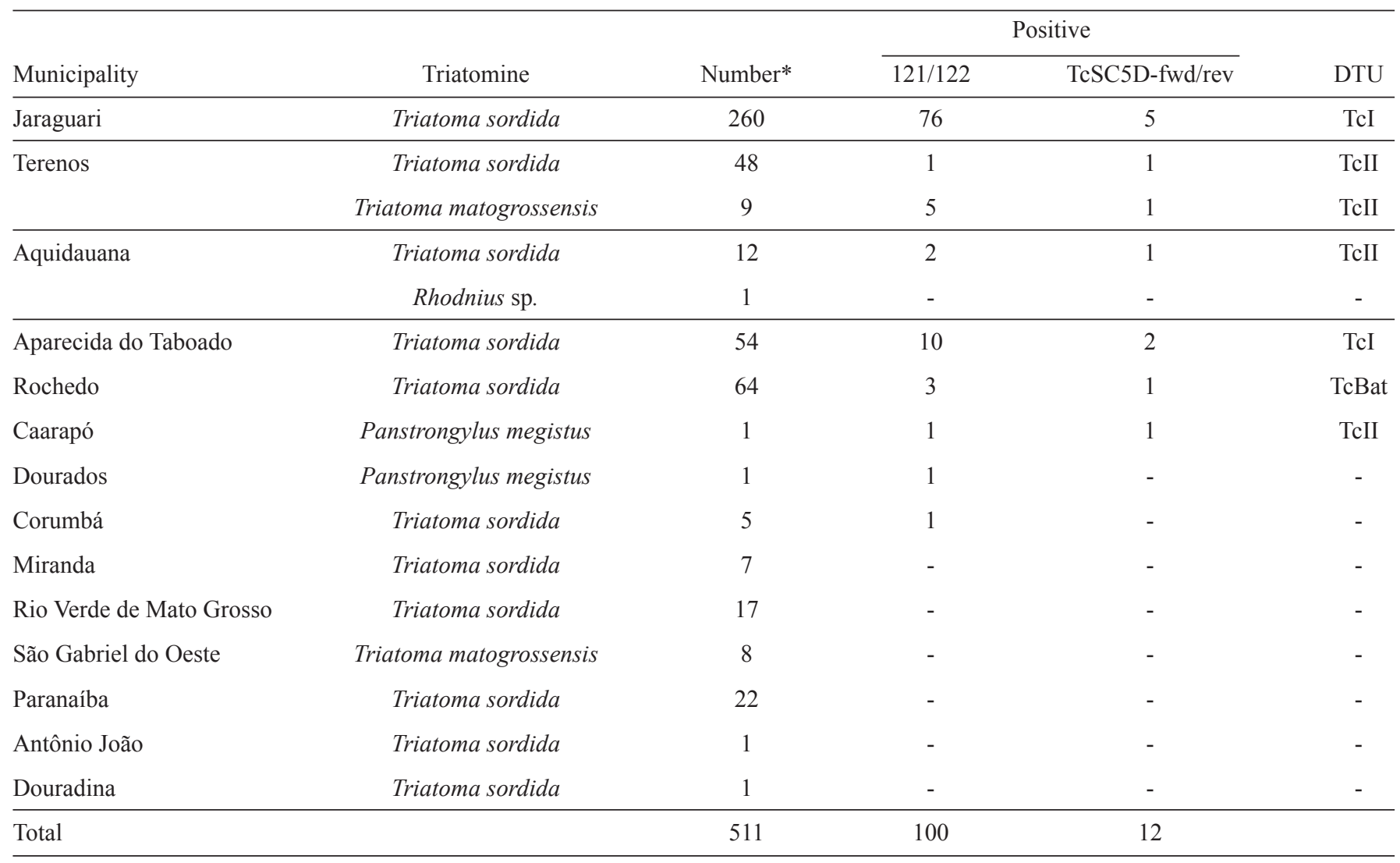

*number of triatomines captured. DTU: discrete typing units.

TcI, TcII and TcBat located in the center, TcI in the east, and TcII in the west (Figure 2).

The PCR product generated from the TcSC5D gene was cloned and sequenced. After alignment and analysis of the nucleotide sequence, TcI, TcII and TcBat were found in $98-100 \%$ of the samples (Figure 3). It was not possible to sequence some of the samples; however, identification via RFLP revealed that DTUs were present in triatomines in those samples.

The reactions using primers for $T$. rangeli (data not shown) did not produce overlapping data, confirming that the amplicons were specific for T. cruzi.

\section{DISCUSSION}

The most commonly captured triatomine was $T$. sordida, which was similar to what was observed in previous studies, showing that this species, which is usually considered secondary, is the most frequently encountered species in $\mathrm{MS}^{4,26,27}$. Triatoma sordida is native to the Cerrado, the biome in which State of Mato Grosso do Sul as well as the transition areas of Maranhão, Piauí, Bahia, the Pantanal and the eastern Chaco are located ${ }^{39}$. This was also the species that harbored the greatest variety of DTUs (TcI, TcII and TcBat). As this species was the most frequently encountered, the likelihood of finding the largest number of infected insect species as well as a greater variety of DTUs was higher.

Insect vectors usually occupy wild environments. However, if their habitat is degraded, they can relocate near human habitations, such as corrals, sties or chicken coops as well as other peridomiciliary constructions. Although all captured triatomines were found in peridomiciles, their mere coexistence with an insect vector increases the chances of infection ${ }^{40}$. One notable factor is that TcII was associated with the severe forms of Chagas disease that were found south of the Amazon region ${ }^{41,42}$; however, other factors are also associated with a higher or lower pathogenicity of the parasite ${ }^{43}$, and its presence near residences is therefore reason to focus attention on the control of triatomines, even though this DTU was found less frequently in this study.

Trypanosoma cruzi is extremely successful, as observed by its continental distribution and its broad host range, which was replicated in our State of Mato Grosso do Sul data. The DTUs found in this work are common in MS, and other studies have identified their presence in the Pantanal region ${ }^{22,44}$. Figure 2 shows that the central region of State of Mato Grosso do Sul had the largest variety of DTUs, presenting TcI, TcII and TcBat (first report of natural infection in triatomines).

Although TcI was also found in the western area of the state $^{22,44}$, this DTU was found to infect triatomines in only 


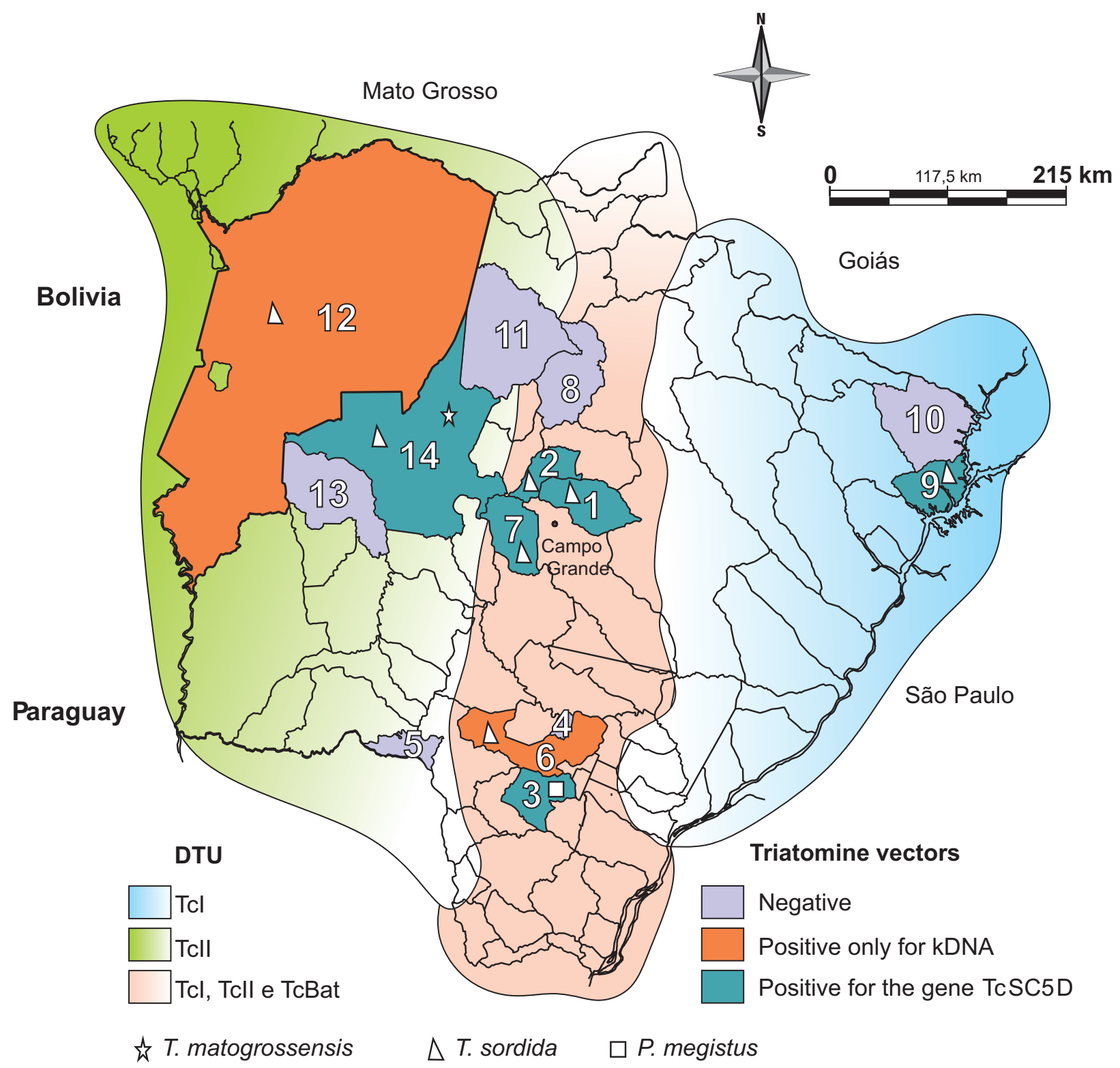

FIGURE 2 - Map of the State of Mato Grosso do Sul, Brazil, highlighting the cities where the triatomines were captured and the distribution of the DTUs found in infected insects. 1: Jaraguari; 2: Rochedo; 3: Caarapó; 4: Douradina; 5: Antônio João; 6: Dourados; 7: Terenos; 8: São Gabriel do Oeste; 9: Aparecida do Taboado; 10: Paranaíba; 11: Rio Verde de Mato Grosso; 12: Corumbá; 13: Miranda; 14: Aquidauana. DTU: discrete typing units; kDNA: kinetoplast deoxyribonucleic acid. T.: Triatoma; P.: Panstrongylus.

the central and eastern areas of the state. Other studies have demonstrated the presence of TcI in São Paulo (SP) ${ }^{45}$ and Minas Gerais $(\mathrm{MG})^{46}$, neighboring states to the East of MS, and in the City of Aparecida do Taboado. However, the occurrence of more than one DTU was observed in SP and MG. One of the factors that may be associated with finding only one TcI in the eastern area of MS may be that it is the most anthropized portion of the state ${ }^{47}$, with large agropastoral formations that reduce the availability of meat for triatomines. As T. sordida was the most abundant species, is predominantly ornithophilous and was obtained from henhouse peridomiciles, finding other DTUs in the studied sites might be difficult. The incidence of TcII was higher in the west, which is similar to the results of previous work with vectors and other wild animals, but this DTU was found mainly in the Pantanal region $^{44,48}$. One possible explanation for this localization is that the region is preserved (in relation to the eastern state), leading to an increased supply of hosts as food sources for the insect vectors, thus facilitating the movement of the parasite. Studies indicate the occurrence of at least approximately 124 species of mammals in the Pantanal region alone ${ }^{49-52}$, but this is only an estimate, and further studies may confirm or refute this hypothesis. However, as the dispersion and isolation of T. cruzi is limited by the dispersion of their hosts, which include several orders of mammals and triatomines ${ }^{53}$, this idea deserves more attention. 


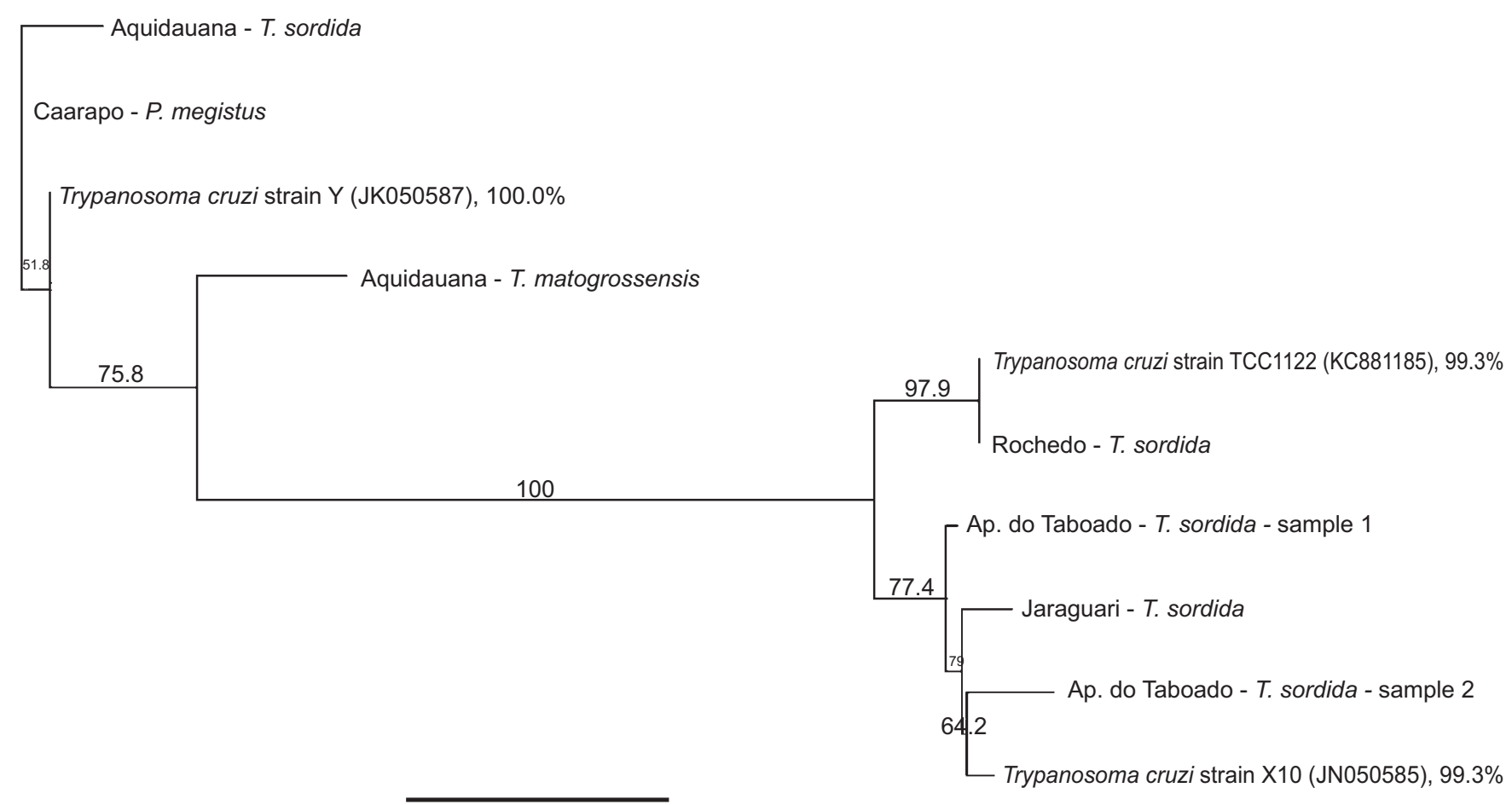

0.02

FIGURE 3 - Partial sequence of the TcSC5d gene. Phylogenetic position of the samples of different genotypes in relation to other DTUs of Trypanosoma cruzi. The analysis was performed with 1,000 bootstrap replicates. The number in parentheses next to the accession number is the GenBank. The scale bar indicates the nucleotide substitutions per site. DTU: discrete typing units. T.: Triatoma; P.: Panstrongylus.

Other studies have demonstrated that TcIII is present in central $\mathrm{MS}^{45}$, which is the same area where TcI is prevalent, more specifically, in the community of Furnas do Dionísio, Jaraguari. This is a rural Quilombola community located $45 \mathrm{~km}$ from Campo Grande, the capital of MS. The community comprises approximately 1,031ha, with modest brick houses that are often near wood sties, chicken coops and pens. However, although Marcili et al. ${ }^{45}$ found TcIII circulating in dogs, the present study showed that only TcI circulated in triatomines and TcII circulated in bats (data not shown) in this community. TcI is a DTU that is widely distributed from South to North America, with most of the isolates from the Amazon region ${ }^{54-57}$. Although TcI is known to be predominantly wild and the source of more frequent, serious infections in humans in Central America, Venezuela ${ }^{58}$ and even in the Amazon region, studies have shown that TcI can manifest severe forms of Chagas disease, especially when co-infection occurs in humans with different DTUs ${ }^{42,59}$. In this case, the epidemiological situation of the studied community has drawn attention because it is located between hills, resulting in a high frequency of infected insects and a large number of natural and artificial ecotopes, as described by Cominetti et al. ${ }^{26}$; it is therefore an ideal environment for triatomine colony infestations. Moreover, the observed TcII infection of bats leads to the question of whether there is overlap between peridomestic and sylvatic cycles that leads to an exchange of the T. cruzi types found in the area. Eco-epidemiological and molecular studies are needed in this region and are now being performed to elucidate this question.

The same types found in the central areas of MS, except for TcBat, were also found in the State of Paraná ${ }^{60}$, which is a route of passage for DTUs (Figure 2). However, it can be inferred from our data, in contrast to other studies ${ }^{44,45,48}$, that it is not possible to delimit DTUs to a specific region. The overlap of DTUs can result from the variety of intricate types of dispersion of the parasite due to the peculiar mechanisms of vector reinfestation ${ }^{61}$ the wide variety of hosts, which are abundant and conspicuous in the Cerrado ${ }^{19}$, and from environmental heterogeneity ${ }^{62}$.

Despite the fact that were did not demonstrate mixed infection by TcI and TcII in insect vectors, as reported by Abolis et al. ${ }^{60}$, this phenomenon may also occur in MS because the conditions for these mixed infections in triatomines are present in this state. Three DTUs were identified in the center of the state and in nearby municipalities. In addition, the Cerrado biome, which covers a large portion of MS, has significant horizontal variation, with open fields, capons, woods, forests and wetlands that potentially coexist in the same region ${ }^{19}$. These data add more strength to the idea that the distribution of the parasite is very wide and dynamic.

TcBat, a trypanosome that, until now, had been found only in bats and a child ${ }^{63}$, has been identified in T. sordida. This 
finding extends the distribution of this DTU in the state, as it was previously described only in the Pantanal region of $\mathrm{MS}^{22,48}$. Additionally, this is the first report of this DTU in a naturally infected triatomine, which had not been previously described, even after attempts at laboratory infection ${ }^{22}$. However, it is expected that the incidence of this DTU is more frequent because it is most closely related to TcI, the most widely distributed DTU in MS, and has finally been identified to infect a triatomine. In the same region, TcII was found in a sample of DNA extracted from the blood of an armadillo (Euphractus sexcinctus) (data not shown).

This study demonstrates the occurrence of overlapping DTUs in the State of Mato Grosso do Sul. The geographical distributions of the DTUs follow different patterns, with TcI, TcII and TcBat in the center, TcI predominantly in the east, and TcII in the west. Furthermore, TcI was the most frequent DTU in triatomines, followed by TcII and TcBat. This study provides greater insight into the distribution of T. cruzi in Brazil, but further studies may reveal a more defined mosaic distribution of DTUs in MS over the long term.

\section{ACKNOWLEDGMENTS}

The authors wish to thank the Laboratório Regional de Entomologia, Núcleo Regional Saúde, and Secretaria de Estado de Saúde for assistance and Dr. Marta M.G. Teixeira (Universidade de São Paulo, Brazil) for the generous gift of T. cruzi and T. rangeli genomic DNA.

\section{CONFLICT OF INTEREST}

The authors declare that there is no conflict of interest.

\section{FINANCIAL SUPPORT}

Support for this work was provided by Embrapa Gado de Corte, Conselho Nacional de Desenvolvimento Científico e Tecnológico (CNPQ) and Fundação de Apoio ao Desenvolvimento do Ensino, Ciência e Tecnologia do Estado de Mato Grosso do Sul (Fundect-MS). A PhD scholarship was provided by Coordenação de Aperfeiçoamento de Pessoal de Nivel Superior (CAPES).

\section{REFERENCES}

1. Miles MA, Feliciangeli MD, Arias AR. American trypanosomiasis (Chagas disease) and the role of molecular epidemiology in guiding control strategies. BMJ 2003; 7404:1444-1448.

2. Guhl F, Schofield CJ. Population genetics and control of Triatominae. Parasitol Today 1996; 5:169-170.

3. Roellig DM, Brown EL, Barnabé C, Tibayrenc M, Steurer FJ, Yabsley MJ. Molecular typing of Trypanosoma cruzi isolates, United States. Emerg Infect Dis 2008; 7:1123-1125.

4. Almeida PS, Ceretti Júnior W, Obara MT, Santos HR, Barata JM. Survey of Triatominae (Hemiptera: Reduviidae) fauna in domestic environments and natural infection by Trypanosomatidae in the State of Mato Grosso do Sul. Rev Soc Bras Med Trop 2008; 4:374-380.

5. Yeo M, Acosta N, Llewellyn M, Sanchez H, Adamson S, Miles GA, et al. Origins of Chagas disease: Didelphis species are natural hosts of Trypanosoma cruzi I and armadillos hosts of Trypanosoma cruzi II, including hybrids. Int J Parasitol 2004; 35:225-233.

6. Rassi Jr A, Rassi A, Marin-Neto JA. Chagas disease. Lancet 2010; 375:1388-1402.

7. Tibayrenc M, Neubauer K, Barnabé C, Guerrini F, Skarecky D, Ayala F. Genetic characterization of six parasitic protozoa: parity betweem ramdom primer DNA typing and multilocus enzyme electrophoresis. Proc Natl Acad Sci USA 1993; 4:1335-1339.

8. Gaunt MW, Yeo M, Frame IA, Stothard JR, Carrasco HJ, Taylor MC, et al. Mechanism of genetic exchange in American trypanosomes. Nature 2003; 6926:936-939.

9. Miles MA, Toye PJ, Oswald SC, Godfrey DG. The identification by isoenzyme patterns of two distinct strain-groups of Trypanosoma cruzi circulating independently in a rural area of Brazil. Trans $\mathrm{R}$ Soc Trop Med Hyg 1997; 3:217-225.

10. Miles MA, Cedillos RA, Povoa MM, Souza AA, Prata A, Macedo V. Do radically dissimilar Trypanosoma cruzi strains (zymodemes) cause Venezuelan and Brazilian forms of Chagas' disease? Lancet 1981; 1:1338-1340.

11. Miles MA, Arias JR, Souza AA. Chagas' disease in the Amazon basin: V. Periurban palms as habitats of Rhodnius robustus and Rhodnius pictipes-triatomine vectors of Chagas' disease. Mem Inst Oswaldo Cruz 1983; 78:391-398

12. Miles MA, Souza A, Povoa M, Shaw JJ, Lainson R, Toye PJ. Isozymic heterogeneity of Trypanosoma cruzi in the first autochthonous patients with Chagas' disease in Amazonian Brazil. Nature 1978; 5656:819-821.

13. Devera R, Fernandes O, Coura JR. Should Trypanosoma cruzi be called "cruzi" complex? A review of the parasite diversity and the potential of selecting population after in Vitro culturing and mice infection. Mem Inst Oswaldo Cruz 2003; 1:1-12.

14. Fernandes O, Souto RP, Castro JA, Pereira JB, Fernandes NC, Junqueira AC, et al. Brazilian isolates of Trypanosoma cruzi from human and triatomines classificated into two lineages using miniexon and ribosomal RNA sequence. Am J Trop Med Hyg 1998; 6:807-811.

15. Souto RP, Fernandes O, Macedo AM, Campbell DA, Zingales B. DNA markers define two major phylogenetic lineages of Trypanosoma cruzi. Mol Biochem Parasitol 1996; 2:141-152.

16. Zingales B, Souto RP, Mangia RH, Lisboa CV, Campbell DA, Coura $\mathrm{JR}$, et al. Molecular epidemiology of American trypanosomiasis in Brazil based on dimorphisms of rRNA and mini-exon gene sequences. Int J Parasitol 1998; 1:105-112.

17. Brisse S, Verhoef J, Tibayrenc M. Characterisation of large and small subunit rRNA and miniexon genes further supports the distinction of six Trypanosoma cruzi lineages. Int J Parasitol 2001; 11:1218-1226.

18. Coura JR. Trypanosomiasis, chagas disease. Ciênc Cult 2003; 1: 30-33.

19. Machado CA, Ayala FJ. Nucleotide sequences provide evidence of genetic exchange among distantly related lineages of Trypanosoma cruzi. Proc Natl Acad Sci USA 2001; 13:7396-7401.

20. Silva AV, Bosco SMG, Langoni H, Bagagli E. Study of Toxoplasma infection in Brazilian wild mammals: Serological evidence in Dasypus novemcinctus Linnaeus, 1758 and Euphractus sexcinctus Wagler, 1830. Vet Parasitol 2006; 1:81-83.

21. Zingales B, Andrade SG, Briones MR, Campbell DA, Chiari E, Fernandes O, et al. New consensus for Trypanosoma cruzi 
intraspecific nomenclature: second revision meeting recommends TCI to TCVI. Mem Inst Oswaldo Cruz 2009; 7:1051-1054.

22. Marcili A, Lima L, Cavazzana M, Junqueira AC, Veludo HH, Maia Da Silva F, et al. A new genotype of Trypanosoma cruzi associated with bats evidenced by phylogenetic analyses using SSU rDNA, cytochrome $\mathrm{b}$ and Histone H2B genes and genotyping based on ITS1 rDNA. Parasitology 2009; 6:641-655.

23. Instituto Brasileiro de Geografia e Estatística (IBGE) [Internet]. Brasilia: IBGE. Available at: http://www.ibge.gov.br/estadosat/ perfil.php?sigla $=\mathrm{ms}$.

24. Simon MF, Grether R, Queiroz LP, Skema C, Pennington RT, Hughes CE. Recent assembly of the Cerrado, a neotropical plant diversity hotspot, by in situ evolution of adaptations to fire. Proc Natl Acad Sci USA 2009; 48:20359-20364.

25. Harris MB, Tomas WM, Mourão G, Silva CJ, Guimarães E, Sonoda F. Desafios para proteger o Pantanal brasileiro: ameaças e iniciativas em conservação. Megadiversidade 2005; 1:156-164.

26. Cominetti MC, Andreotti R, Oshiro ET, Dorval MEMC. Epidemiological factors related to the transmission risk of Trypanosoma cruzi in a Quilombola community, State of Mato Grosso do Sul, Brazil. Rev Soc Bras Med Trop 2011; 5:575-581.

27. Cominetti MC, Almeida RF, Gonçalves GM, Andreotti R. Monitoring Trypanosoma cruzi infection in triatomines using PCR in Mato Grosso do Sul, Brazil. Rev Soc Bras Med Trop 2013; 3:277-280.

28. Carcavallo RU, Rodrigues MEF, Galvão C, Rocha DS, Girón IG, Arocha MAO, et al. Habitats e fauna relacionada. In: Carcavallo RU, Girón IG, Jurberg J, Lent H, editors. Atlas dos vetores da doença de Chagas nas Américas. Rio de Janeiro: Fundação Oswaldo Cruz; 1997. p. 107-244.

29. Souza MA. Morphobiological characterization of Trypanosoma cruzi Chagas, 1909 and its distinction from other trypanosomes. Mem Inst Oswaldo Cruz 1999; 94:205-210.

30. Westenberger SJ, Sturm NR, Yanega D, Podlipaev SA, Zeledón R, Campbell DA, et al. Trypanosomatid biodiversity in Costa Rica: genotyping of parasites from Heteroptera using the spliced leader RNA gene. Parasitology 2004; 129:537-547

31. Wincker P, Britto C, Pereira JB, Cardoso MA, Oelemann W, Morel CM. Use of a simplified polymerase chain reaction procedure to detect Trypanosoma cruzi in blood samples patients in a rural endemic area. Am J Trop Med Hyg 1994; 51:771-777.

32. Schijman AG, Bisio M, Orellana L, Sued M, Duffy T, Jaramillo $\mathrm{AMM}$, et al. International study to evaluate PCR methods for detection of Trypanosoma cruzi DNA in blood samples from Chagas disease patients. PLoS Negl Trop Dis 2011; 5:e931.

33. Chiurillo MA, Crisante G, Rojas A, Peralta A, Dias M, Guevara $\mathrm{P}$, et al. Detection of Trypanosoma cruzi and Trypanosoma rangeli infection by duplex PCR assay based on telomeric sequences. Clin Diagn Lab Immunol 2003; 10:775-779

34. Cosentino RO, Agüero F. A simple strain typing assay for Trypanosoma cruzi: discrimination of major evolutionary lineages from a single amplification product. PLoS Negl Trop Dis 2012; 7:e1777.

35. Sanger F, Nicklen S, Coulson AR. DNA sequencing with chainterminating inhibitors. Proc Natl Acad Sci 1977; 74:5463-5467

36. Hall TA. BioEdit: a user-friendly biological sequence alignment editor and analysis program for Windows 95/98/NT. Nucl Acids Symp Ser 1999; 41:95-98.

37. Altschul SF, Gish W, Miller W, Myers EW, Lipman DJ. Basic local alignment search tool. J Mol Biol 1990; 215:403-410.

38. Drummond AJ, Ashton BMC, Heled J, Kearse M, Moir R, StonesHavas S, et al. Geneious v 4.8. [Software]. 2009. Available at: http:// www.geneious.com/
39. Forattini OP. Biogeography, origin, and distribution of triatominae domiciliarity in Brazil. Rev Saude Publica 1980; 6:964-968.

40. Toledo MJO, Kühl JB, Silva SV, Gasperi V, Araújo SM. Biogeography, origin, and distribution of triatominae domiciliarity in Brazil. Rev Saude Publica 1997; 3:197-203.

41. Burgos JM, Altcheh J, Bisio M, Duffy T, Valadares HM, Seidenstein ME, et al. Direct molecular profiling of minicircle signatures and lineages of Trypanosoma cruzi bloodstream populations causing congenital Chagas disease. Int J Parasitol 2007; 37:1319-1327.

42. del Puerto R, Nishizawa JE, Kikuchi M, Iihoshi N, Roca Y, Avilas C, et al. Lineage analysis of circulating Trypanosoma cruzi parasites and their association with clinical forms of Chagas disease in Bolivia. PLoS Negl Trop Dis 2010; 4:e687.

43. Macedo AM, Machado CR, Oliveira RP, Pena SD. Trypanosoma cruzi: genetic structure of populations and relevance of genetic variability to the pathogenesis of chagas disease. Mem Inst Oswaldo Cruz 2004; 99:1-12.

44. Herrera HM, Lisboa CV, Pinho AP, Olifiers N, Bianchi RC, Rocha FL, et al. The coati (Nasua nasua, Carnivora, Procyonidae) as a reservoir host for the main lineages of Trypanosoma cruzi in the Pantanal region, Brazil. Trans R Soc Trop Med Hyg 2008; 11:1133-1339.

45. Marcili A, Lima L, Valente VC, Valente SA, Batista JS, Junqueira AC, et al. Comparative phylogeography of Trypanosoma cruzi TCIIc: new hosts, association with terrestrial ecotopes, and spatial clustering. Infect Genet Evol 2009; 6:1265-1274.

46. Viana EN. Dinâmica de reinfestações por triatomíneos e alterações ambientais na ecoepidemiologia da doença de Chagas em área de Triatoma sordida Stål 1859 (Hemiptera, Reduviidae, Triatominae) no norte de Minas Gerais, Brasil [PhD thesis]. [Belo Horizonte]: Universidade Federal de Minas Gerais, Instituto de Ciências Biológicas; 2001. 280 p.

47. Machado RB, Ramos Neto MB, Pereira P, Caldas E, Gonçalves D, Santos N, et al. Estimativas de perda da área do Cerrado brasileiro. Brasilia: Conservation International do Brasil; 2004.

48. Cavazzana Jr M, Marcili A, Lima L, Silva FM, Junqueira AC, Veludo $\mathrm{HH}$, et al. Phylogeographical, ecological and biological patterns shown by nuclear (ssrRNA and gGAPDH) and mitochondrial (Cyt b) genes of trypanosomes of the subgenus Schizotrypanum parasitic in Brazilian bats. Int J Parasitol 2010; 3:345-55.

49. Alho CJR, Lacher TE. Mammalian conservation in the Pantanal of Brazil. In: Mares MA, Schmidly DJ, editors. Latin American mammalogy: history, biodiversity and conservation. University of Oklahoma Press; 1991. p. 280-294.

50. Mourão G, Coutinho M, Mauro R, Campos Z, Tomás W, Magnusson W. Aerial surveys of caiman, marsh deer and pampas deer in the Pantanal wetland of Brazil. Biol Cons 2000; 92:175-183.

51. Tomas WM, Lima Borges PA, Rocha HJF, Sá Filho R, Kutchenski Jr F, Udry TV. The potential of the Aquidauana and Miranda rivers, in the Pantanal Wetland, for the conservation of the giant river otter (Pteronura brasilienis). In: Dantas M, Resende EK, Comastri Filho JA, editors. Anais do III Simpósio sobre Recursos Naturais e Socioeconômicos do Pantanal. Corumbá: Empresa Brasileira de Pesquisa Agropecuária - Embrapa-Pantanal; 2002. p. 1-12.

52. Sanderson EW, Chetkiewicz CLB, Medellin RA, Rabinowitz A, Redford KH, Robinson JG, et al. Un análisis geográfico del estado de conservación y distribución de los jaguars através de su área de distribución. In: Medellín RA, Equihua C, Chetkiewicz CLB, Crawshaw Jr PG, Rabinowitz A, Redford KH, et al, editors. El jaguar en el Nuevo milenio. Mexico: Universidad Nacional Autônoma de México, Nova York: Wildlife Conservation Society; 2002. p. $551-560$.

53. Zingales B. Trypanosoma cruzi: one parasite, two parasites or several parasites of chagas disease? Rev Biol 2011; 6b:44-48. 
54. Miles MA, Povoa M, Souza AA, Lainson R, Shaw JJ, Ketteridge DS. Chagas disease in the Amazon Basin. II. The distribution of Trypanosoma cruzi zymodemes 1 and 3 in Pará State, north Brazil. Trans R Soc Trop Med Hyg 1981; 75:667-674.

55. Fernandes O, Santos SS, Cupolillo E, Mendonça B, Derre R, Junqueira $\mathrm{ACV}$, et al. A mini-exon multiplex polymerase chain reaction to distinguish the major groups of Trypanosoma cruzi and T. rangeli in the Brazilian Amazon. Trans R Soc Trop Med Hyg 2001; 95:97-99.

56. Maia da Silva F, Naiff RD, Marcili A, Gordo M, D’Affonseca Neto JA, Naiff MF, et al. Infection rates and genotypes of Trypanosoma rangeli and T. cruzi infecting free-ranging Saguinus bicolor (Callitrichidae), a critically endangered primate of the Amazon Rainforest. Acta Trop 2008; 107:168-173.

57. Marcili A, Valente V, Valente A, Junqueira ACV, Maia da Silva F, Naiff R, et al. Trypanosoma cruzi in Brazilian Amazonia: lineages TCI and TCIIa in wild primates, Rhodnius spp. and in humans with Chagas disease associated with oral transmission. Int J Parasitol 2009; 39:615-623.

58. Miles MA, Cedillos RA, Póvoa MM, Souza AA, Prata A, Macedo V. Do radically dissimilar Trypanosoma cruzi strains (zymodemes) cause Venezuelan and Brazilian forms of Chagas' disease? Lancet 1981; 8234:1338-1340.

59. Burgos JM, Diez M, Vigliano C, Bisio M, Risso M, Duffy T, et al. Molecular identification of Trypanosoma cruzi Discrete Typing Units in end-stage chronic Chagas heart disease and reactivation after heart transplantation. Clin Infect Dis 2010; 51:485-495.

60. Abolis NG, Araújo SM, Toledo MJ, Fernandez MA, Gomes ML. Trypanosoma cruzi I-III in southern Brazil causing individual and mixed infections in humans, sylvatic reservoirs and triatomines. Acta Trop 2011; 3:167-172.

61. Schachter-Broide J, Gürtler RE, Kitron U, Dujardin JD. Temporal variations of wing size and shape of Triatoma infestans (Hemiptera: Reduviidae) populations from Northwestern Argentina using geometric morphometry. J Med Entomol 2009; 5:994-1000.

62. Vaz VC, D'Andrea PS, Jansen AM. Effects of habitat fragmentation on wild mammal infection by Trypanosoma cruzi. Parasitology 2007; 12:1785-1793.

63. Ramírez JD, Hernández C, Montilla M, Zambrano P, Flórez AC, Parra E, et al. First Report of Human Trypanosoma cruzi Infection Attributed to TcBat Genotype. Zoonoses Public Health 2013; 61:477-479. 